\title{
Vegetative Response to Clearcutting and Chopping in a North Florida Flatwoods Forest
}

\author{
WILLIAM H. MOORE, BENEE F. SWINDEL, AND W. STEPHEN TERRY
}

\section{Abstract}

Selected naturally regenerated flatwoods forests were clearcut and chopped in preparing a large, long-term study of the effects of several multiple-use management practices on forest vegetation and wildlife. Early effects of clearcutting and chopping on understory vegetation are reported here. Clearcutting and chopping reduced woody understory coverage from 66 to $18 \%$ of surface area. Common gallberry and saw-palmetto were reduced by 75 and $89 \%$, respectively. Herbaceous species frequency was increased: Panicums by over 3,000\%; bluestems by $173 \%$; grasslikes by over $2,000 \%$; and forbs by $308 \%$. Graphical analyses show an increase in herbaceous species diversity as a result of mechanical site disturbance. Comparing these graphs with those reported on the effects of prescribed burning suggests that the collective vegetative response to mechanical site disturbance is qualitatively similar to the response to fire. Quantitatively the response to mechanical disturbance is more pronounced.

Successful production of wood, cattle, and wildlife in the southern pinelands depends on methods of managing both overstory and understory simultaneously to increase multiple product yields while avoiding environmental and ecological degradation. In 1976 we began a large study to examine various effects of an array of forest management practices on wildlife and wildlife habitat, and on herbage production. Portions of the study area were only burned. An early assessment of the effects fire produced on the understory vegetation was reported by Moore, et al. (1982). Other portions of the study area were clearcut, chopped, and replanted to pines. Reported here is an early assessment of the effects of mechanical site disturbance on understory vegetation, and a comparison of these effects with the earlier reported effects of prescribed fire. The comparison is made to show that mechanical disturbance in natural flatwoods forests has effects similar to prescribed fire-which is widely regarded as a useful tool of range and wildlife managers.

\section{Study Area and Methods}

The 73-ha experimental area is on the University of Florida's Austin Cary Memorial Forest near Gainesville, Alachua County, Florida. When this study began the experimental area was occupied by a naturally regenerated 50 -year old flatwoods forest averaging $20.7 \mathrm{~m}^{2}$ of basal area per ha and $70.8 \%$ crown cover. The overwhelming majority of overstory trees were either slash or longleaf pine. There were a few water oaks and occasionally some other ha rdwood species, especially in wetter spaces. A brief history of the experimental area and a description of the soils on the site are given by Moore et al. (1982). The entire experimental a rea was prescribed burned during the winter of $1975-76$ with no perceptible effect on the overstory.

\footnotetext{
Authors are research wildlife biologist (retired) and research forester, Southeastern Forest Experiment Station, U.S. Forest Service, and range research biologist, School of Forest Resources and Conservation, University of Florida, Gainesville 32611.
}

In September and October of 1976,22 1-ha plots randomly dispersed over the experimental area were selected for subsequent harvest, site preparation, and planting, and the understory vegetation on these plots was surveyed. Survey methods were identical to those described by Moore et al. (1982). Coverage of all woody vegetation less than $1.5 \mathrm{~m}$ high was determined on three $30-\mathrm{m}$ line transects in each plot. Where woody vegetation did not exist, measurements of surface litter coverage were recorded. Herbaceous species frequencies (Brown 1954) were recorded for each 30-cm segment along the same transects, i.e., a species was recorded as present when plant parts intercepted a vertical projection of the transect segment, and absent otherwise. Herbaceous standing biomass was determined by clipping, sorting by species, drying, and weighing all herbaceous biomass on two $1-\mathrm{m}^{2}$ subplots adjacent to each of the 66 transects.

All plots were then clearcut during the fall and winter of 1976-77. All merchantable pine wood was removed. In August and September of 1977, all plots were double chopped with a Marden drum chopper pulled by a skidder. In the winter of 1977-78, some of the plots were hand planted with 1,100 slash pine seedlings per ha. These seedlings are assumed to have had no detectable effect on the vegetative responses reported here.

In September and October of 1978, vegetation was resurveyed exactly as in 1976 except that biomass plots were moved to avoid any residual biases due to previous clipping. The resulting observations were treated as 22 replications of a single treatment (1978 data) versus a control (1976 data), and subjected to paired $t$ tests (Ostle 1963) to determine which species responded significantly to clearcutting and chopping. All changes mentioned in the text were significant at the $1 \%$ level $(P<0.01)$.

\section{Results}

\section{Changes in Woody Plant Coverage}

Of course clearcutting and chopping removed or destroyed all overstory trees in the study plots receiving this treatment. Clearcutting and chopping also reduced woody understory coverage dramatically (Table 1). On the average, tree species were reduced by $65 \%$, shrubs by $75 \%$, and vines by $29 \%$. Litter coverage was reduced by $72 \%$. Coverage of saw-palmetto was reduced from $28 \%$ to $3 \%$ of the surface area; that of common gallberry from 12 to $3 \%$. Of the woody species in the understory, only the blackberries were increased by clearcutting and chopping.

\section{Changes in Herbaceous Species Frequencies}

Clearcutting and chopping greatly increased the frequencies of herbaceous vegetation (Table 2). On the average, frequencies of grasses (see Table 2) increased by $420 \%$. The most notable increase was by the genus Panicum, which occurred on $1.9 \%$ of the transect segments before cutting, and on $63.1 \%$ of them 1 year after chopping. Pineland threeawn was reduced while chalky bluestem increased. Significant trends were noted for several less 
Table 1. Canopy coverage below $1.5 \mathrm{~m}$ of woody plants on line transects before (1976) and after (1978) clearcutting and chopping.

\begin{tabular}{|c|c|c|}
\hline \multirow[b]{2}{*}{ Species } & \multicolumn{2}{|c|}{$\%$ cover } \\
\hline & 1976 & 1978 \\
\hline $\begin{array}{l}\text { Trees } \\
\text { Red maple (Acer rubrum) } \\
\text { Common persimmon (Diospyros virginiana) } \\
\text { Loblollybay (Gordonia lasianthus) } \\
\text { Sweetgum (Liquidambar styraciflua) } \\
\text { Sweetbay (Magnolia virginiana) } \\
\text { Blackgum ( Nyssa sylvatica) } \\
\text { Redbay (Persea borbonia) } \\
\text { Pine (Pinus spp.) } \\
\text { Southern red oak (Quercus falcata) } \\
\text { Bluejack oak (Q. incana) } \\
\text { Sand post oak ( } Q \text {. margetta) } \\
\text { Water oak ( } Q \text {. nigra) } \\
\text { Live oak (Q. virginiana) } \\
\text { Black locust (Robinia pseudo-acacia) }\end{array}$ & $\begin{array}{c}0.6 \\
0.1 \\
<0.05 \\
0.5 \\
0.1 \\
0.3 \\
0.0 \\
<0.05 \\
0.0 \\
0.1 \\
<0.05 \\
1.3 \\
<0.05 \\
0.0\end{array}$ & $\begin{array}{c}0.1^{* * 2} \\
<0.05 \\
<0.05 \\
0.1^{* *} \\
<0.05 \\
0.1 \\
<0.05 \\
0.0 \\
<0.05 \\
<0.05 \\
0.0 \\
0.7^{* *} \\
0.2^{* 1} \\
<0.05\end{array}$ \\
\hline $\begin{array}{l}\text { Shrubs } \\
\text { Dwarf pawpaw (Asimina parvifolia) } \\
\text { American beautyberry (Callicarpa } \\
\text { americana) } \\
\text { Gopherapple (Chrysobalanus oblongifolius) } \\
\text { Dwarf huckleberry (Gaylussacia dumosa) } \\
\text { St. Johnswort (Hypericum spp.) } \\
\text { Large gallberry (Ilex coriacea) } \\
\text { Common gallberry (I. glabra) } \\
\text { Wicky (Kalmia hirsuta) } \\
\text { Lyonia (Lyonia spp.) } \\
\text { Southern waxmrytle (Myrica cerifera) } \\
\text { Running oak (Quercus pumila) } \\
\text { Piedmont azalea (Rhododendron canescens) } \\
\text { Shining sumac (Rhus copallina) } \\
\text { Smooth sumac (R. glabra) } \\
\text { Poison sumac (R. vernix) } \\
\text { Saw-palmetto (Serenoa repens) } \\
\text { Red chokeberry (Sorbus arbutifolia) } \\
\text { Queensdelight (Stillingia sylvatica) } \\
\text { Blueberry (Vaccinium spp.) } \\
\text { Farkleberry (V. arboreum) } \\
\text { Ground blueberry (V. myrsinites) } \\
\text { Possumhaw viburnum (Viburnum nudum) }\end{array}$ & $\begin{array}{c}0.3 \\
<0.05 \\
0.2 \\
3.7 \\
0.1 \\
0.4 \\
12.3 \\
0.4 \\
3.0 \\
0.6 \\
3.2 \\
0.2 \\
0.1 \\
<0.05 \\
0.1 \\
27.6 \\
0.7 \\
<0.05 \\
1.0 \\
0.0 \\
1.8 \\
<0.05\end{array}$ & $\begin{array}{c}<0.05^{* *} \\
<0.05 \\
0.0^{* *} \\
1.1^{* *} \\
0.1 \\
<0.05^{* *} \\
2.9^{* *} \\
<0.05^{* *} \\
0.8^{* *} \\
0.3^{* *} \\
1.2^{* *} \\
<0.05^{* *} \\
0.3^{*} \\
<0.05 \\
<0.05 \\
3.2^{* *} \\
0.9^{2} \\
<0.05 \\
0.3^{* *} \\
<0.05 \\
0.8^{* *} \\
<0.05\end{array}$ \\
\hline $\begin{array}{l}\text { Vines } \\
\text { Yellow jessamine (Gelsemium sempervirens) } \\
\text { Japanese honeysucklc (Lonicena japonica) } \\
\text { Virginia creeper (Parthenocissus } \\
\text { quinquefolia) } \\
\text { Poisonivy (Rhus radicans) } \\
\text { Blackberry (Rubus spp.) } \\
\text { Earleaf greenbrier (Smilax auriculata) } \\
\text { Catleaf greenbrier (S. glauca) } \\
\text { Laurel greenbrier (S. laurifolia) } \\
\text { Muscadine grape (Vitis rotundifolia) }\end{array}$ & $\begin{array}{c}1.4 \\
0.0 \\
\\
0.0 \\
<0.05 \\
0.2 \\
0.8 \\
0.0 \\
0.0 \\
2.4\end{array}$ & $\begin{array}{c}0.4^{* *} \\
<0.05^{*} \\
\\
<0.05 \\
<0.05 \\
1.7^{* *} \\
0.8 \\
<0.05 \\
<0.05 \\
0.5^{* *}\end{array}$ \\
\hline
\end{tabular}

*implies change is significant at $5 \%$ level.

$2 *$ implies change is significant at $1 \% \mathrm{level}$.

abundant-but important-grasses. Barestem paspalum, a species of major importance to bobwhite (Murray and Frye 1957) increased from less than $0.05 \%$ frequency to $3.3 \%$ (Table 2 ). Toothachegrass and lopside indiangrass, both desirable cattle forages, were never abundant and were nearly eliminated.

Grasslikes (see Table 2) increased by $2,250 \%$ and as a result constitute an important part (nearly $20 \%$ ) of the herbaceous flora. Greatest gains occurred with the flatsedges, spikesedge, beakrushes, and razorsedges. The importance of these species to cattle and wildlife is generally unknown.

Ferns occurred on about one-third of the transect segments and were not affected by site preparation. About $95 \%$ of the ferns were bracken, a species poisonous to cattle when ingested in large quantities.
After chopping, forbs made up about $25 \%$ of the herbaceous flora (Table 2) after increasing more than 300\%. Legumes (important to wildlife and cattle) increased from $2.1 \%$ frequency to $4.5 \%$. Eupatorium also increased, but grassleaf goldaster remained about the same and aster diminished.

\section{Changes in Herbage Biomass}

Trends in herbage biomass were similar to those observed for herbage frequency (Table 2). Total standing biomass was 245 $\mathrm{kg} / \mathrm{ha}$ before site treatment and $1,867 \mathrm{~kg} /$ ha 1 year afterwards, a $662 \%$ increase. Grasses increased from 40 to $1,017 \mathrm{~kg} / \mathrm{ha}$. They accounted for $16 \%$ of the total herbage biomass before treatment and $54 \%$ afterwards. The bulk of this increase was due to the response of the genera Panicum and Andropogon. Pineland threeawn decreased. Forbs were the next most important herbaceous group and increased from 27 to $371 \mathrm{~kg} / \mathrm{ha}(20 \%$ of the total herbage biomass) as a result of site treatment. Legumes (mainly partridgepea) increased from 3 to $79 \mathrm{~kg} /$ ha. Ferns (over $80 \%$ bracken) increased from 173 to $305 \mathrm{~kg} /$ ha. Ferns comprised $70 \%$ of the total herbage biomass before treatment; $16 \%$ afterwards. Grasslikes (see Table 2) increased from 5 to $174 \mathrm{~kg} / \mathrm{ha}$, nearly $10 \%$ of the post treatment biomass. Flatsedges, spikesedge, beakrushes, and razorsedges were more represented.

\section{Discussion}

\section{Managerial Considerations}

In the flatwoods, pine site preparation and range chopping similar to that applied here generally produce a forage response ranging from 2,000 to $6,000 \mathrm{~kg} /$ ha (Moore 1974, White 1975, White 1977). Grasses typically make up about two-thirds or more of the production. Bluestems, many of them highly regarded as cattle forage, typically respond dramatically and frequently make up the bulk of the grass biomass in early years. White (1977) found bluestem still accounted for nearly half of the grass biomass 5 years after treatment. In the study reported here, total herbage biomass was less than $2,000 \mathrm{~kg}$ / ha 1 year after double chopping and grasses accounted for only a little over half of that. Bluestems (see.Table 2) made up only about one-third, while panicums-a less desirable forage group-accounted for over $50 \%$ of grass biomass.

Site history and delay in chopping may explain the smaller response of desirable forage species observed here. The site had not been burned or otherwise disturbed for many years. It was dominated by a thick, woody understory with sparse herbaceous vegetation. The preliminary burn was incomplete, did not consume the heavy surface litter, and few herbs invaded the site. As a result, seed sources at the time of chopping were undoubtedly scarce. Moreover, due to contractual difficulties, chopping actually was done in late summer - the time when seeds and fruits a re maturing. Many desirable plants and their seeds were thus destroyed. Also, late summer is a period of high soil moisture so summer chopping does not typically result in good shrub control.

When cattle forage and wildlife habitat improvement is a management objective, better shrub control should be obtained if mechanical site preparation is done during the drier part of the dormant season (Lewis 1972, Moore 1974). And herbaceous seeds will have matured and will be incorporated into the soil for better spring germination.

\section{Ecological Considerations}

It is important to consider the total floral response to various forest and range management practices. Forest management (especially in the slash pine ecosystem) has been subjected to the criticism that it too often tends to produce a pine monoculture which excludes other plant species on lands planted to pines. Mechanical site preparation is sometimes identified as a pine cultural practice that so discriminates against competing species that it jeopardizes the species diversity deemed healthy for the ecosystem. It is instructive to examine the responses to clearcutting and chopping detailed in previous sections with these considerations in mind. 
Table 2. Frequency of occurrence of herbaceous plants on line transects before (1976) and after (1978) clearcutting and chopping, and corresponding standing biomass on clipped subplots.

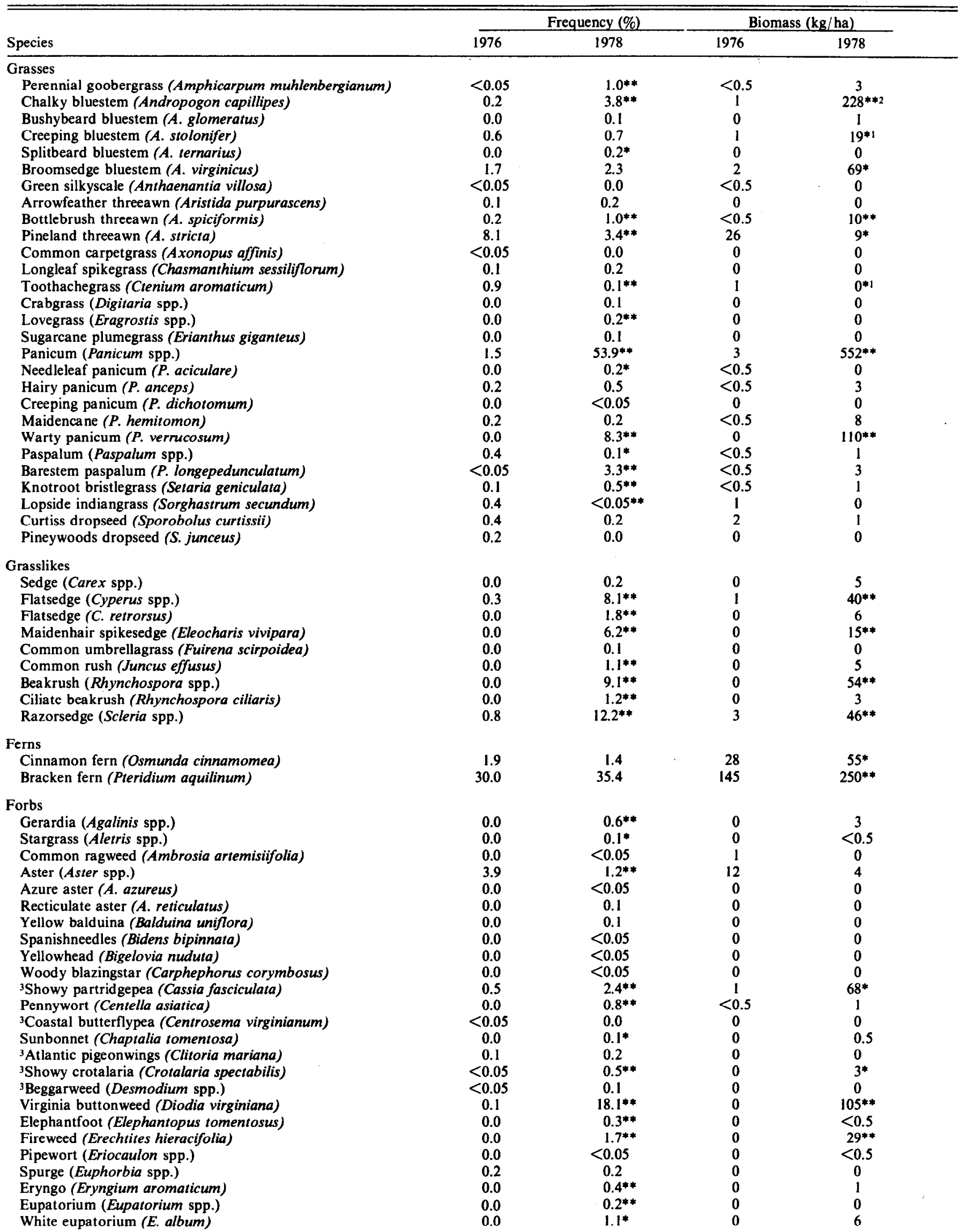




\begin{tabular}{|c|c|c|c|c|}
\hline \multirow[b]{2}{*}{ Species } & \multicolumn{2}{|c|}{ Frequency $(\%)$} & \multicolumn{2}{|c|}{ Biomass (kg/ha) } \\
\hline & 1976 & 1978 & 1976 & 1978 \\
\hline Dogfennel eupatorium ( $E$. capillifolium) & 0.0 & $1.3^{* *}$ & 0 & $57 *$ \\
\hline${ }^{3}$ Downy milkpea (Galactia volubilis) & 1.1 & 0.7 & 1 & 2 \\
\hline Turnsole (Heliotropium indicum) & 0.0 & $<0.05$ & 0 & 0 \\
\hline Grassleaf goldaster (Heterotheca graminifolia) & 2.6 & 2.2 & 5 & 20 \\
\hline St. Johnswort (Hypericum spp.) & 0.1 & $1.6^{* *}$ & 1 & 3 \\
\hline St. Johnswort (H. cistifolium) & 0.0 & $0.1^{*}$ & $\mathbf{0}$ & 2 \\
\hline Pineweed ( $H$. gentianoides) & 0.0 & $<0.05$ & 0 & 0 \\
\hline St. Peterswort (H. stans) & 0.0 & 0.1 & 0 & $<0.5$ \\
\hline Redroot (Lachnanthes caroliniana) & 0.0 & $<0.05$ & 0 & 0 \\
\hline Bogbuttons (Lachnocaulon spp.) & 0.0 & $<0.05$ & 0 & 0 \\
\hline Pineweed (Lechea spp.) & 0.0 & $0.2^{* *}$ & 0 & 1 \\
\hline${ }^{3}$ Hairy lespedeza (Lespedeza hirtha) & 0.0 & $<0.05$ & 0 & 0 \\
\hline Mint (Lamiaceae spp.) & 0.0 & $<0.05$ & 0 & 0 \\
\hline Gayfeather (Liatris garberi) & 0.0 & $1.7 * *$ & 1 & 3 \\
\hline Lobelia (Lobelia spp.) & 0.0 & $0.1^{*}$ & 0 & 1 \\
\hline Seedbox (Ludwigia spp.) & 0.0 & $2.2^{* *}$ & 0 & $9 *$ \\
\hline Seedbox (Ludwigia virgata) & $<0.05$ & 0.1 & 0 & 0 \\
\hline Orange candyweed (Polygala lutea) & 0.0 & $0.5^{* *}$ & 0 & $2 * *$ \\
\hline Blackroot (Pterocaulon pycnostachyum) & 0.0 & $1.7^{* *}$ & 0 & $13^{*}$ \\
\hline Mudder (Rubiaceae spp.) & 0.0 & $0.3^{* *}$ & 0 & 2 \\
\hline Meadowbeauty (Rhexia spp.) & 0.2 & $1.3^{* *}$ & $<0.5$ & $10^{* *}$ \\
\hline Meadowbeauty ( $R$. alifanus) & 0.0 & $<0.05$ & 0 & $<$ \\
\hline Maryland meadowbeauty ( $R$. mariana) & 0.0 & $0.1^{*}$ & 0 & 0 \\
\hline Meadowbeauty ( $R$. petiolata) & 0.0 & $<0.05$ & 0 & $<0.5$ \\
\hline${ }^{3}$ Rhynchosia (Rhynchosia spp.) & 0.0 & $<0.05$ & $<0.5$ & 3 \\
\hline Mexicanclover (Richardia scabra) & 0.0 & $<0.05$ & 0 & 0 \\
\hline Rosegentian (Sabatia spp.) & 0.0 & $<0.05$ & $\mathbf{0}$ & $<0.5$ \\
\hline Hooded pitcherplant (Sarracenia minor) & $<0.05$ & $<0.05$ & 0 & 0 \\
\hline Figwort (Scrophulariaceae) & 0.0 & $<0.05$ & 0 & 0 \\
\hline Goldenrod (Solidago spp.) & 0.0 & $0.6^{* *}$ & 0 & $<0.5$ \\
\hline Sowthistle (Sonchus spp.) & 0.0 & 0.1 & 0 & 0 \\
\hline${ }^{3}$ Pencilflower (Stylosanthes biflora) & $<0.05$ & 0.0 & 0 & 0 \\
\hline Shoe-buttons (Sygonanthus flavidulus) & 0.0 & $0.9^{* *}$ & 0 & $2^{* *}$ \\
\hline${ }^{3}$ Brownhair tephrosia (Tephrosia spicata) & 0.2 & $0.5^{*}$ & $<0.5$ & $3 *$ \\
\hline Spiderwort (Tradescatia spp.) & 0.0 & $<0.05$ & 0 & 0 \\
\hline Deertongue (Trilisa ordoratissima) & $<0.05$ & $<0.05$ & 1 & $<0.5$ \\
\hline Stinging needle (Urtica chamaedryoides) & $<0.05$ & $<0.05$ & 0 & 0 \\
\hline Wood violet (Viola triloba) & 0.0 & $0.1^{*}$ & 0 & 0 \\
\hline Yelloweyedgrass (Xyris ambigua) & 0.5 & $3.0^{* *}$ & 2 & $10^{*}$ \\
\hline
\end{tabular}

${ }^{*}$ implies change is significant at $5 \%$ level.

${ }^{2 * *}$ implies change is significant at $1 \%$ level.

${ }^{3}$ Legumes (all FABACEAE)

Coverage of woody species in the understory before and after site treatment is depicted in Figure 1. Coverage before treatment is plotted (on a logarithmic scale) along the abscissa, coverage after treatment in a similar way along the ordinate. The straight line at $45^{\circ}$ depicts exactly no change. Species that diminish after treatment plot below the line; those that increase plot above it. Only those species that changed significantly $(P<0.01)$ are labeled. The label is an acronym consisting of the first two letters of the Latin genus and species names. Thus, saw-palmetto (Serenoa repens) is labeled SERE, common gallberry (llex glabra) is ILGL, blackberry (Rubus spp.) is RUSP, etc. Examining the entire graph for the collective response of the community, the obvious effect of clearcutting and chopping is a dramatic (recall the scales are logarithmic) reduction in woody understory coverage. It is interesting from an ecological viewpoint that the reduction is relatively no more severe in relatively rare species than in relatively common ones, and that the total number of species was not reduced by the disturbance. Indeed, 44 woody species were found on the transects both before and after treatment (cf. Table 1).

Frequency responses of the herbaceous understory are plotted in an analogous way in Figure 2. From this graph the response of the herbaceous understory is seen to be quite different from that of the woody understory. The overwhelming tendency is that herbaceous plants increase in frequency, especially if they are rare or absent prior to site disturbance. Substantial numbers of herbaceous species appear only after treatment. Thus, 22 species of grasses were recorded before treatment, 27 afterwards. Only 20 species of forbs occurred on the transects before cutting, while 64 species were recorded after chopping. In all, 47 species of herbs were recorded on transects before pastures were cut and chopped; 102 species were recorded after treatment. Only pineland threeawn, toothachegrass, lopside indiangrass, and aster were significantly $(\boldsymbol{P}<0.01)$ reduced.

Finally, herbaceous biomass is plotted in an analogous way in Figure 3. Recall that the destructive sampling employed required that biomass harvesting be performed on distinct subplots during resurvey. The resulting greater variation in the two observations is expressed in greater scatter in Figure 3 than in Figure 2, and in fewer changes judged statistically significant. Still, the overwhelming tendency for herbaceous species, especially for those previously rare, is to increase after site disturbance.

It is especially interesting to compare the responses to clearcutting and chopping reported here to the responses reported earlier (Moore et al. 1982) to prescribed fire. The responses depicted in figures 1,2 , and 3 in this paper are identical to those in the corresponding figures in the earlier paper-except for the treatments imposed. The surveys were conducted simultaneously and used identical survey and analytical methods. Comparing the 


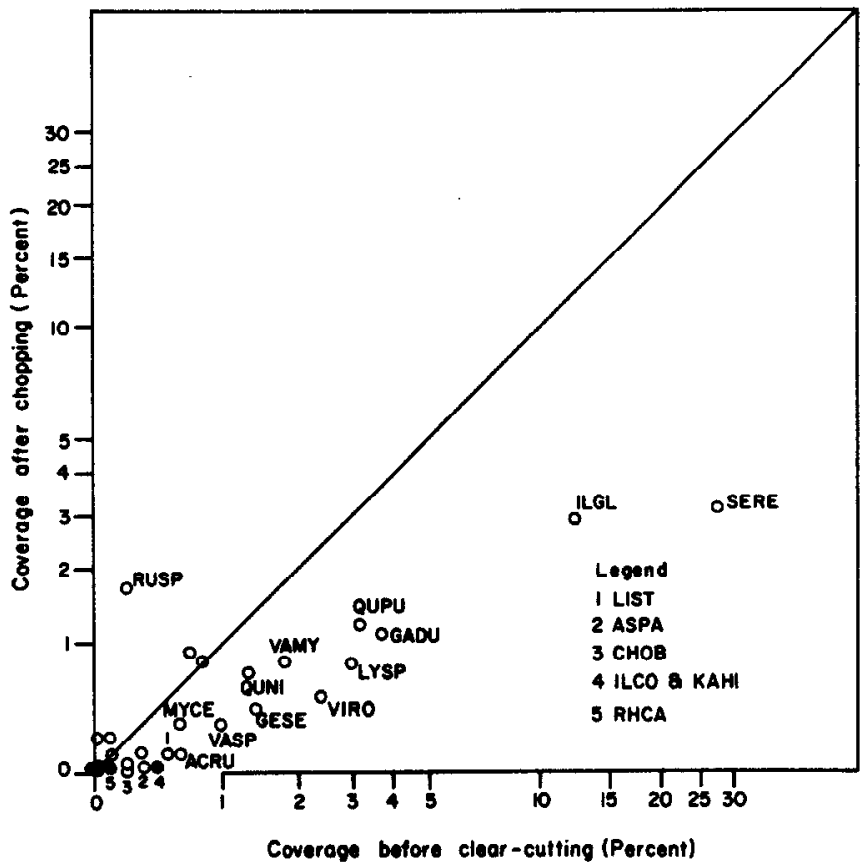

Fig. 1. Coverage of woody species below 1.5 meters before and after clear-cutting and chopping.

results figure-by-figure shows that the collective vegetative response to clearcutting and chopping is qualitatively strikingly similar to the response to prescribed fire. Quantitatively the response to mechanical site preparation is much more pronounced.

\section{Conclusions}

Evidence in this study of the effects of clearcutting and chopping, and in a previously reported study of the effects of prescribed fire, indicates that mechanical site disturbance in flatwoods forests

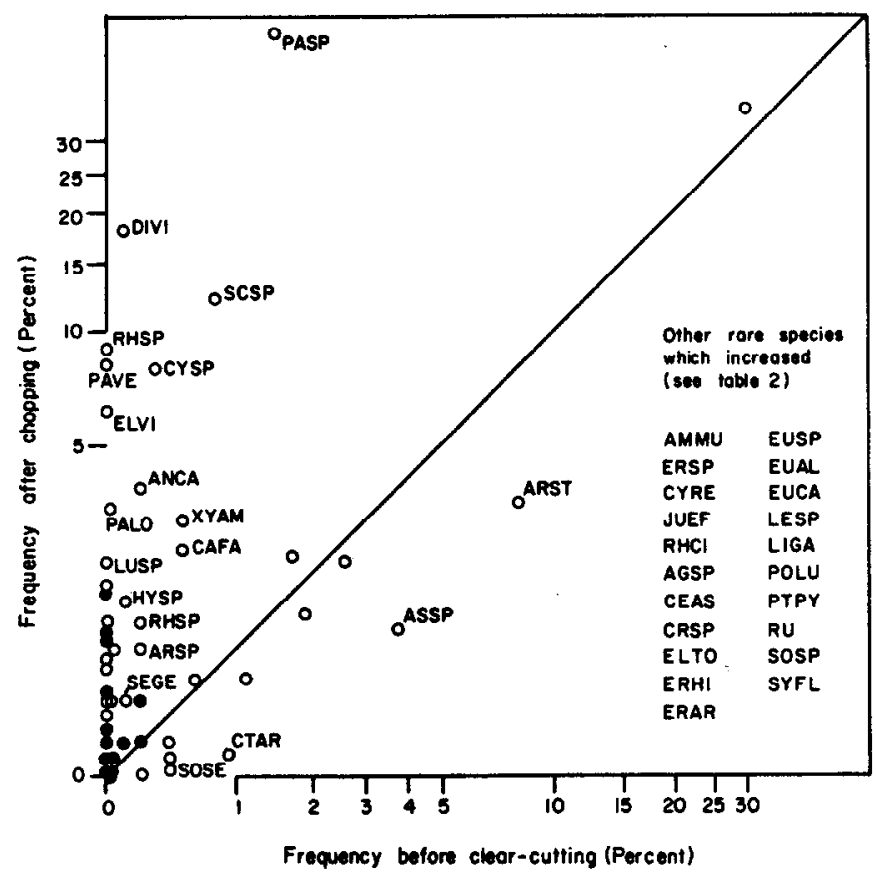

Fig. 2. Frequency of herbaceous vegetation before and after clear-curting and chopping.

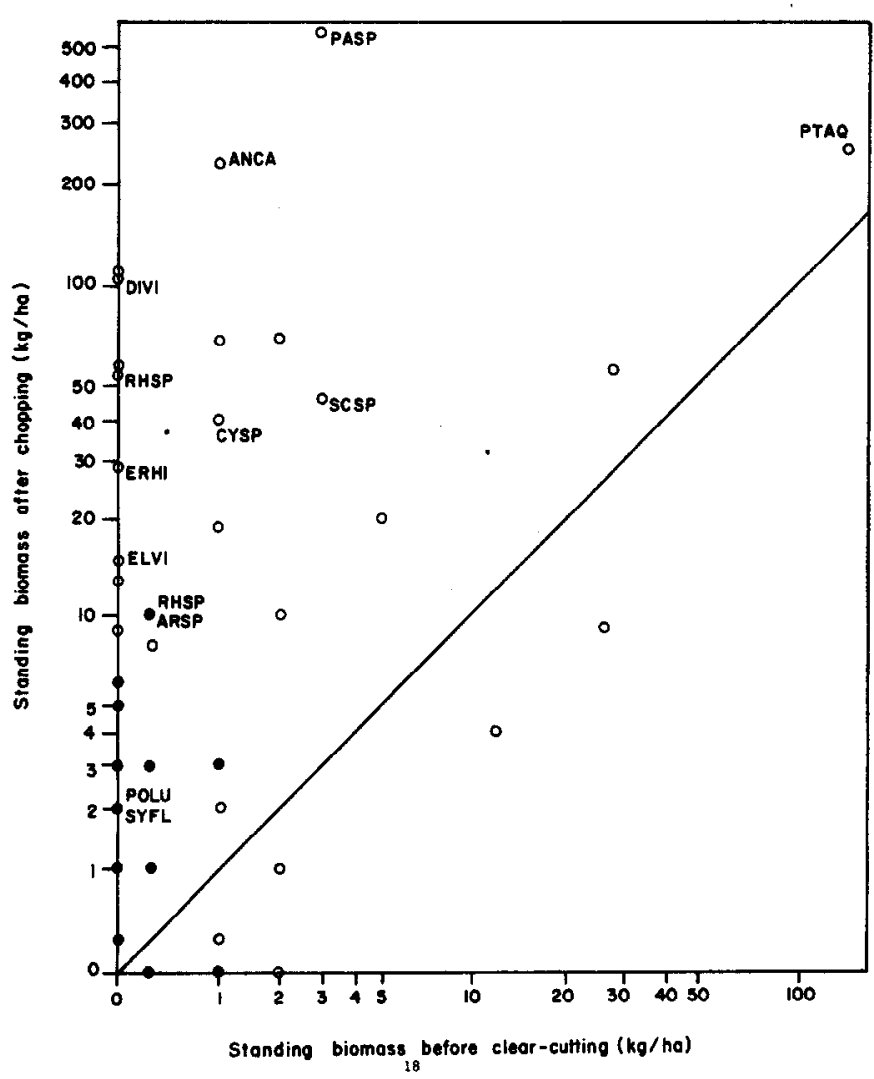

Fig. 3. Herbaceous standing biomass before and after clear-cutting and chopping.

of north Florida diminishes overabundant woody understory cover more than fire. The diminution is relatively uniform over the spectrum from rare to common species. There is no evidence in our data that clearcutting and chopping actually reduces the total number of woody species in the understory.

Burning and mechanical disturbance tends to increase both the frequency and weights of herbaceous species, including those that were previously rare or not present. The response to mechanical disturbance is more pronounced that than to fire. Apparently total number of understory species and understory species diversity are increased by either disturbance, but more so by mechanical disturbance than by fire.

\section{Literature Cited}

Brown, D. 1954. Methods of Surveying and Measuring Vegetation. Bulletin 42. Commonwealth Bureau of Pastures and Field Crops, Hurley, Berks, England. 223 p.

Lewis, C.E. 1972. Chopping and webbing control saw-palmetto in South Florida. U.S. Dep. Agr. Forest Serv., Southeastern Forest Exp. Sta Res. Note SE-177. 6 p.

Moore, W.H. 1974. Some effects of chopping saw-palmetto-pineland threeawn range in South Florida. J. Range Manage. 27:101-104.

Moore, W.H., B.F. Swindel, and W.S. Terry. 1982. Vegetative response to prescribed fire in a North Florida flatwoods forest. J. Range Manage. 35:

Ostle, B. 1963. Statistics in Research. The lowa State University Press, Ames. 585 p.

White, L.D. 1975. Intensive forest management effects on understory plant production. In: Forest soils of the southeastern coastal plains. Sch. Forest Res. and Conserv. Res. Rep. No. 2. Univ. Florida, Gainesville. p 76-89.

White, L.D. 1977. Forage production in a 5-year old fertilized slash pine plantation. J. Range Manage. 30:131-134.

Murray, R.W., and O.E. Frye, Jr. 1957. The bobwhite quail and its management in Florida, Game Pub. No. 2. Florida Game and Fresh Water Fish Comm. $56 \mathrm{p}$. 